\title{
Buying Behaviour of Consumers towards Millet Based Food Products in Hyderabad District of Telangana, India
}

\author{
P. Alekhya ${ }^{1}$ and A. Raj Shravanthi ${ }^{2 *}$ \\ ${ }^{1}$ Green Fields Institute of Agriculture, Hyderabad, India \\ ${ }^{2}$ School of Agri-Business and Rural Management, Dr. Rajendra Prasad Central Agricultural \\ University, Pusa (Samastipur) - 848 125, India \\ *Corresponding author
}

\section{A B S T R A C T}

\section{Keywords \\ Millets, Consumer acceptance, Millet based products, Nutritional benefits Areca nut, UHPLC, Redox titration, Vitamin $\mathrm{B}_{6}$, Vitamin C}

\section{Article Info}

Accepted: 04 September 2019 Available Online: 10 October 2019
Millets are not only powerhouses of nutrients; they also play the role of hedging against several insecurities (food, fodder, fiber, health etc). However the cultivation of millets has declined in recent years, which has to be revived due to its nutritional benefits and the consumers should be encouraged to include millets in their regular diet to fight malnutrition. Therefore it is necessary to understand the consumer acceptance of millet based products and also identify the attributes influencing buying behaviour of consumer towards millet products to achieve nutritional consumption of food and to fight several health complications of this generation. With this background the current study was undertaken to identify the factors influencing buying behavior of millet products among sample consumers and to assess consumer acceptance of millet products offered by different organization in the study area. To meet the objectives data was collected from 100 consumers across the Hyderabad city of Telangana. Results revealed that income of the respondents was not influencing the purchase of millet based products. Among all the channels of information dissemination on health benefits of millet products, social media has more influence as it can reach all the age groups easily. It was also found that health benefits was the major factor influencing the consumption of millet based products by the respondents in the study area which is in support of the fact that millets are one of the world's healthiest foods. Majority of the millets were having high price and very few millets were having reasonable price which was affecting the purchasing decision of the consumer especially in the case of brown top millet. All the millets were frequently available in the market except brown top millet which was rarely available and there was demand from the respondents for brown top millet because of its multiple health benefits. Majority of the respondent's ranked flavour as a major attribute for consumer acceptance of the millet based product. Therefore the flavour part in millet based products should be enhanced to increase consumer acceptance by addition of natural or artificial essence.

\section{Introduction}

Millets have been cultivated since prehistoric times in regions of North Africa and Central
Asia, though its origin is ambiguous. Most millet is produced in Asia and Africa. In Europe and the United States, millet is grown mainly as forage for poultry and as bird feed 
(Robert, 2004). Millet is a collective name used to describe a number of different smallgrained cereal grasses. Although millets do not derive from one plant species, they do share consistent common features. Millets are usually subdivided into "large millets" (sorghum and pearl millet) and "small millets" (finger-, barnyard-, little-, kodo-, foxtail- and proso millet). Finger millet is often mentioned separately from other small millets (Bommy and Maheswari, 2016). Brown top millet is also millet which is widely grown in southern states of India especially Karnataka.

Millets, often termed nutri-cereals, are a 'Smart Food' as they are not only highly nutritious but target some of the highest malnutrition problems. For example, Pearl millet is high in iron, zinc and folic acid which is not only among the highest micronutrient needs but also particularly important for adolescent girls and women. Finger millet has three times the amount of calcium as milk also critical for women and babies. Millets are also high in antioxidants and important for fighting diabetes and heart disease which are at significantly increasing levels in India. (ICRISAT, 2016).

Indian millets produce multiple securities such as securities in food, nutrition, fodder, fibre, health, livelihood and ecology (Bommy and Maheswari, 2016).

National Nutrition Monitoring Bureau has reported that the consumption of millets was higher in the states of Gujarat (pearl millet, maize), Karnataka (finger millet), Maharastra (sorghum) but negligible in the states of Kerala, Orissa, West Bengal and Tamil Nadu where rice is the most consumed cereal (NNMB, 2006).

Cereals are being consumed as main staple by Indians that constitute $70-80 \%$ of the total energy intake (Gopalan et al., 2009). Recent study by NNMB on dietary profile of urban Indians [from the Chennai Urban Rural Epidemiology Study (CURES)] revealed that only $2 \%$ of the total calories $(6.7 \mathrm{~g} / \mathrm{d})$ were contributed by the millets (Radhika et al., 2011)

There is a need to restore the lost interest in millets that deserves recognition for its nutritional qualities and potential health benefits in management of diabetes mellitus, obesity and hyperlipidemia (Ranjita et al., 2016)

Value addition and improving health benefits of millets by combining with traditional cereals and milk and by applying advanced technologies for their processing and preservation opens new avenues for the product diversification (Sudha et al., 2016).

According to Samuel (2016), Minor millets such as foxtail millet, little millet, kodo millet, proso millet and barnyard millet, as well as the major millets such as sorghum (great millet), bajra (pearl millet) and ragi (finger millet) are increasingly being included in the food basket of rural and urban households. They cost less than rice or wheat, and keep you healthier.

The new cooking recipes from minor millets have great potential as protein and minerals rich supplementary foods to alleviate Protein Calories Malnutrition (PCM) and mineral deficiency diseases prevalent among school going children (Rajput, 2019).

Millets are not only powerhouses of nutrients, they also play the role of hedging against several insecurities (food, fodder, fibre, health etc). However the cultivation of millets has declined in recent years, which has to be revived due to its nutritional benefits and the consumers should be encouraged to include millets in their regular diet to fight malnutrition. Therefore it is necessary to 
understand the consumer acceptance of millet based products and also identify the attributes influencing buying behaviour of consumer towards millet products to achieve nutritional consumption of food and to fight several health complications of this generation. With this background the current study was undertaken to study the buying behaviour of consumers towards millet based food products in Hyderabad district of Telangana. The specific objectives of the study were to identify the factors influencing buying behavior of millet products among sample consumers and to assess consumer acceptance of millet products offered by different organization in the study area.

\section{Review of Literature}

Ballolli et al., (2001) has developed nutraceuticals enriched barnyard millet cookies by incorporating nuts and dry fruits. The barnyard millet cookies were highly acceptable with light and crisp texture, pleasant aroma and excellent taste.

Varnashree et al., (2008) evaluated that idlis prepared by using ragi and ragi flour along with other ingredients such as parboiled rice and black gram dhal flour in different ratio. The study concluded that ragi could be used to replace rice in the preparation of idli enhancing the nutritional quality without considerable effect on the quality parameters of idli.

Vijayakumar et al., (2009) carried out a study to expand the utility of Kodo (Pasapalum scrobiculatum) and Barnyard (Echinochloa colona) millets by incorporating them in whole wheat flour and defatted soy flour mixture and studied the impact of millet flour blend on different quality characteristics of chapathi. Nutrient density and taste was increased due to incorporation of millet flour and soy flour. The 30 percent millet flour blend incorporated composite flour based chapatti was highly acceptable.

Kulkarani et al., (2011) developed value added millet based traditional food products and tested their acceptability. The products developed were proso millet sweet pongal, little millet paddu and dosa with chakramuni leaves, little millet idli with methi leaves and carrot, little millet uppma with drumstick leaves and with bengal gram leaves, barnyard millet based uppma with drumstick leaves, foxtails millet vada with greens and foxtail millet based besibelebhath. For management of lifestyle disorders the value added millet based traditional products are considered as sustainable, nutritious, cost effective and to alleviate hidden hunger.

Shukla and Srivastava (2011) they have developed noodles for diabetic patients that which is having finger millet as a ingredient. The Glycemic Index (GI) of 30\% finger millet incorporated noodles was observed significantly lower (45.13) than control noodles (62.59). It was found that finger millet flour incorporated noodles to be nutritious and showed hypoglycemic effect.

Akoth et al., (2012) has developed instant breakfast cereals from optimized flours of pearl millet, red and white sorghum. The developed breakfast cereals had better nutrient attributes in comparison to their control products.

The developed breakfast cereals from optimized flours of sorghum and millet were having high nutritive value than the similar products that are available in the markets and are more accepted by the consumers.

Geeta et al., (2012) conducted a study on nutritional scenario of fast food among women in Bhagalpur Town, Bihar. The women with higher educational qualifications, younger age 
group and high income level are consuming more fast food. The consumption of Sodium chloride was higher due to consumption of fast food.

Kalidas and Mahendran (2017) in their study they suggested that for increasing in sales of millet products extra quantity should be offered with the normal pack or freebies like the items useful for kitchen should be offered with the pack or reducing the prices will make the consumers to purchase more quantities.

\section{Materials and Methods}

Hyderabad district was selected purposively to study the consumer acceptability of various millet products among different income level of consumers available in the city. Rajendra nagar, Hightech city, Kukatpally, LB Nagar, Dilshukhnagar, Tarnaka, Kothapet, Boduppal, Ramananthapuram, Vasavi Nagar areas were chosen to interview the respondents.

Millets like foxtail millet, little millet, finger millet, proso millet, jowar, pearl millet, kodo millet, brown top millet and their processed products were selected for the purpose of the study. The processed products includes cakes, biscuits, mixtures, muruku, instant roti, papads, ladoos, flours, multi grain flour mixes, millet bars, idly mix, dosa mix, upma mix, pizza base of millet based products of different brands were selected.

To study the factors influencing the buying behavior, the products of different brands of millets were selected and they were targeted as health foods. Purposive sampling method was 100 consumers across the Hyderabad city for elucidating the information.

The data required for the study has been gathered by personal interview from the respondents of the selected area. Data has been collected from the consumers about their food habits, attributes of millet foods and factors that have influenced them to buy the products. The collected data has been analyzed by using frequencies, percentages, graphs and garret ranking.

\section{Results and Discussion}

The objectives of the study i.e. analysing factors influencing buying behaviour of millet products among sample consumers and consumer acceptance of millet products offered by different organization in the study area were analysed using different techniques such as tabular analysis, bar graphs and garrette ranking. The results of the analysis are discussed in detail.

Most of the respondents were consuming millets in the form of cooked rice, converting the raw millet rice into flour and rawa. With the flour idly and dosa mixes, roti and jawa (thick consistency soup) were prepared and with rawa upma, kichadis were prepared. Biscuits, cakes, mixtures, muruku (snacks), ladoos (sweet), Namkeen mix, millets bite papads, millet pizza base and millets bars were consumed.

\section{Income level of the Respondents}

The monthly family income of the respondents was obtained in rupees and it was categorized into 5 groups based on range of income. $<1$ lakh, 1-3 lakhs, 4-6 lakhs, 7-9 lakhs and >9 lakhs. The income level of sample respondents is presented in the Figure 1.

Among the 100 respondents, 10 respondents were having annual income less than 1 lakh, 7 respondents were having an annual income between 1-3 lakhs, 15 respondents were having annual income between 4-6 lakhs, 27 respondents were having annual income between 7 -9 lakhs and 41 respondents were having an annual income more than 9 lakhs. 
Income of the respondents was not influencing the purchase of millet based products because the income of majority of the respondents was more than five lakhs which shows that income and consumption of millet based products was not correlated but the quantity of the purchase was varying because of the price of the product.

\section{Medium influencing Awareness on Millet Products}

The awareness level of millet based products among sample respondents in analysed and presented in Figure 2.

Among the 100 respondents, 7 per cent of the respondents were aware about millet products through newspapers, 1 per cent by magazines and 2 per cent by TV scrolling.

Leaf lets, banners and banners/cut-outs, SMS blast had no influence on awareness of millet based products. Around 35 per cent of the respondents were aware about millets products through peer group and 55 per cent of the respondents were aware due to other reasons such as social media like you tube, face book, instagram, Dr. Khadar Valli's messages etc. Few of the respondents said that they were influenced by Dr khadar Valli diet plan. Recently majority of the respondents have changed their diet plan due to the influence of Dr. Khadar Valli diet and awareness about the health benefits of millets.

Dr Khadar Valli is a renowned independent scientist and millets expert who has written books on millets in daily diet to combat diabetes, cancer, thyroid, skin care etc. and also presented the same on many platforms such as you-tube, workshops, conferences, stage shows etc. Among all the channels social media has more influence as it can reach all the age groups easily.

\section{Reasons for consumption of millet products}

The major reasons for consuming millet products were taste, health benefits, weight loss, and other reasons such as habit since childhood, interest in trying new products etc.

The factors influencing consumption of millet products by the respondents are presented in Table 1.

From the above table it can be observed that out of 100 respondents 57 per cent were consuming millet based products for health benefits followed by 26 per cent for taste, 13 per cent for loosing weight and 4 per cent respondents were consuming millet based products for other reasons like habituated from child hood, new product preference etc.

The results prove that health benefits was the major factor influencing the consumption of millet based products by the respondents in the study area which is in support of the fact that millets are as one of the world's healthiest foods. According to nutritionists, millets are rich in iron, copper, manganese, calcium, phosphorus, magnesium and B vitamins.

They also come with antioxidants, flavonoids, certain amino acids and tryptophan. (The Economic Times, 2016)

\section{Influence of Price on Millet Products}

Millets are considered as cheaper substitutes to cereals. Therefore to understand the price of millet based products on consumption by the respondents, data was collected on price of millet products on a 3 points scale. Score 1 was given for low price, 2 was given for reasonable price and 3 was given for high price. The results are presented in Table 2 .

Among the 100 consumers, 82 per cent consumers were consuming foxtail millet and 
18 per cent consumers were not consuming them. Out of the 82 respondents consuming millet based products, 71 per cent respondents ranked it as high price, 10 per cent respondents ranked it as reasonable price and 1 per cent ranked as low price. Little millet was consumed by 52 per cent of the respondents and 48 per cent were not consuming them. About 49 per cent ranked it as high price and 3 per cent ranked it as reasonable price. Pearl millet was consumed by 12 per cent of the respondents and remaining 88 per cent of the respondents were not consuming them. Around 9 per cent of respondents ranked it as high price and 3 per cent respondents ranked it as reasonable price. Kodo millet was consumed by 42 per cent of the respondents and 58 per cent of the respondents were not consuming them. Out of 42 per cent respondents, 39 per cent of the respondents ranked it as high price and 3 per cent ranked it as reasonable price. Finger millet was consumed by 43 per cent of the respondents and for remaining 58 per cent respondents, finger millet was not a part of their diet. Out of the 43 per cent 28 per cent ranked it as high price and 15 per cent ranked it as reasonable price. Proso millet was consumed by 22 per cent of the respondents and remaining 78 per cent were not consuming them. Among them 21 per cent ranked it as high price and 1 per cent ranked it as reasonable price. Jowar was consumed by 39 per cent of the respondents and 61 per cent of the respondents were not consuming it. 23 per cent ranked it as high price and 16 per cent ranked it as reasonable price. Browntop millet was consumed by 36 per cent of the respondents and remaining 64 per cent of the consumers were not consuming them. All the 36 per cent respondents ranked it as high price. Majority of the consumers ranked that the price of millets was high, few respondents ranked as reasonable price and low price was ranked by very few. The price of brown top millet was very high when compared with other type of millets. Majority of the consumers opined that finger millet, pearl millet and jowar was having reasonable price while foxtail millet, little millet, kodo millet and proso millet was priced high. Browntop millet was opined to be very costly. Majority of the millets were having high price and very few millets were having reasonable price which was affecting the purchasing decision of the consumer especially in the case of brown top millet.

As urban consumers increasingly prefer small millets, traders are jumping onto the healthfood bandwagon to cash in on the growing trend. Besides scarce supplies, the traders' rising interest has led to an increase in the price of some varieties such as foxtail millet and browntop millet over the past couple of months. While prices of the browntop millet, considered to be rich in fibre, have doubled to ₹260-300 a kg since November, that of foxtail millet have risen by over 40 per cent to ₹70-100 in the retail segment. (The Hindu BusinessLine, 2019)

\section{Availability of Millet Based Products in the retail Stores}

The data on availability of product in market was collected using 2 point scale: frequently and rarely. The results are presented in Table 3. From the above Table it can be interpreted that foxtail millet, little millet, pearl millet, kodo millet, finger millet, proso millet and jowar were frequently available in the market and were having a varied range of products. More than 90 per cent of respondents opined that foxtail millet, little millet, pearl millet, kodo millet, finger millet, proso millet and jowar were frequently available in the market. Around 78 per cent of the respondents remarked that brown top millet was rarely available in the market. 
Table.1 Factors influencing consumption of millet based products

$($ No. of Respondents $=100)$

\begin{tabular}{|c|c|c|}
\hline S.No. & Factors & Percentage \\
\hline $\mathbf{1}$ & Health benefits & 57 \\
\hline $\mathbf{2}$ & Weight Loss & 13 \\
\hline $\mathbf{3}$ & Taste & 26 \\
\hline $\mathbf{4}$ & Other reasons & 04 \\
\hline & Total & $\mathbf{1 0 0}$ \\
\hline
\end{tabular}

Table.2 Influence of price on consumption of millet products

\begin{tabular}{|c|c|c|c|}
\hline Type of Millet & High Price & Reasonable Price & Low Price \\
\hline Foxtail Millet & 71 & 10 & 1 \\
\hline Little Millet & 49 & 3 & 0 \\
\hline Pearl Millet & 9 & 3 & 0 \\
\hline Kodo Millet & 39 & 3 & 0 \\
\hline Finger Millet & 28 & 15 & 0 \\
\hline Proso Millet & 21 & 1 & 0 \\
\hline Sorghum/Jowar & 23 & 16 & 0 \\
\hline Browntop Millet & 36 & 0 & 0 \\
\hline
\end{tabular}

Table.3 Availability of millet based products

\begin{tabular}{|c|c|c|}
\hline Type of Millet & Frequently & Rarely \\
\hline Foxtail millet & 98 & 2 \\
\hline Little millet & 96 & 4 \\
\hline Pearl millet & 98 & 2 \\
\hline Kodo millet & 93 & 7 \\
\hline Finger millet & 95 & 5 \\
\hline Proso millet & 95 & 5 \\
\hline Sorghum/Jowar & 98 & 2 \\
\hline Browntop millet & 22 & 78 \\
\hline
\end{tabular}

Table.4 Attribute-wise Garrette ranking for consumer acceptance of millet products

\begin{tabular}{|c|c|c|c|c|c|c|c|c|}
\hline Attributes & $\begin{array}{c}\text { Foxtail } \\
\text { Millet }\end{array}$ & $\begin{array}{c}\text { Little } \\
\text { Millet }\end{array}$ & $\begin{array}{c}\text { Pearl } \\
\text { Millet }\end{array}$ & $\begin{array}{c}\text { Kodo } \\
\text { Millet }\end{array}$ & $\begin{array}{c}\text { Finger } \\
\text { Millet }\end{array}$ & $\begin{array}{c}\text { Proso } \\
\text { Millet }\end{array}$ & Jowar & $\begin{array}{c}\text { Brown top } \\
\text { Millet }\end{array}$ \\
\hline Taste & Fourth & Fourth & Fourth & Fourth & Fourth & Fourth & Fourth & Fourth \\
\hline Appearance & Third & Third & Third & Third & Third & Third & Second & Third \\
\hline Texture & Second & Second & First & Second & Second & Second & First & Second \\
\hline Flavour & First & First & Second & First & First & First & Third & First \\
\hline
\end{tabular}


Fig.1 Division of respondents based on income level

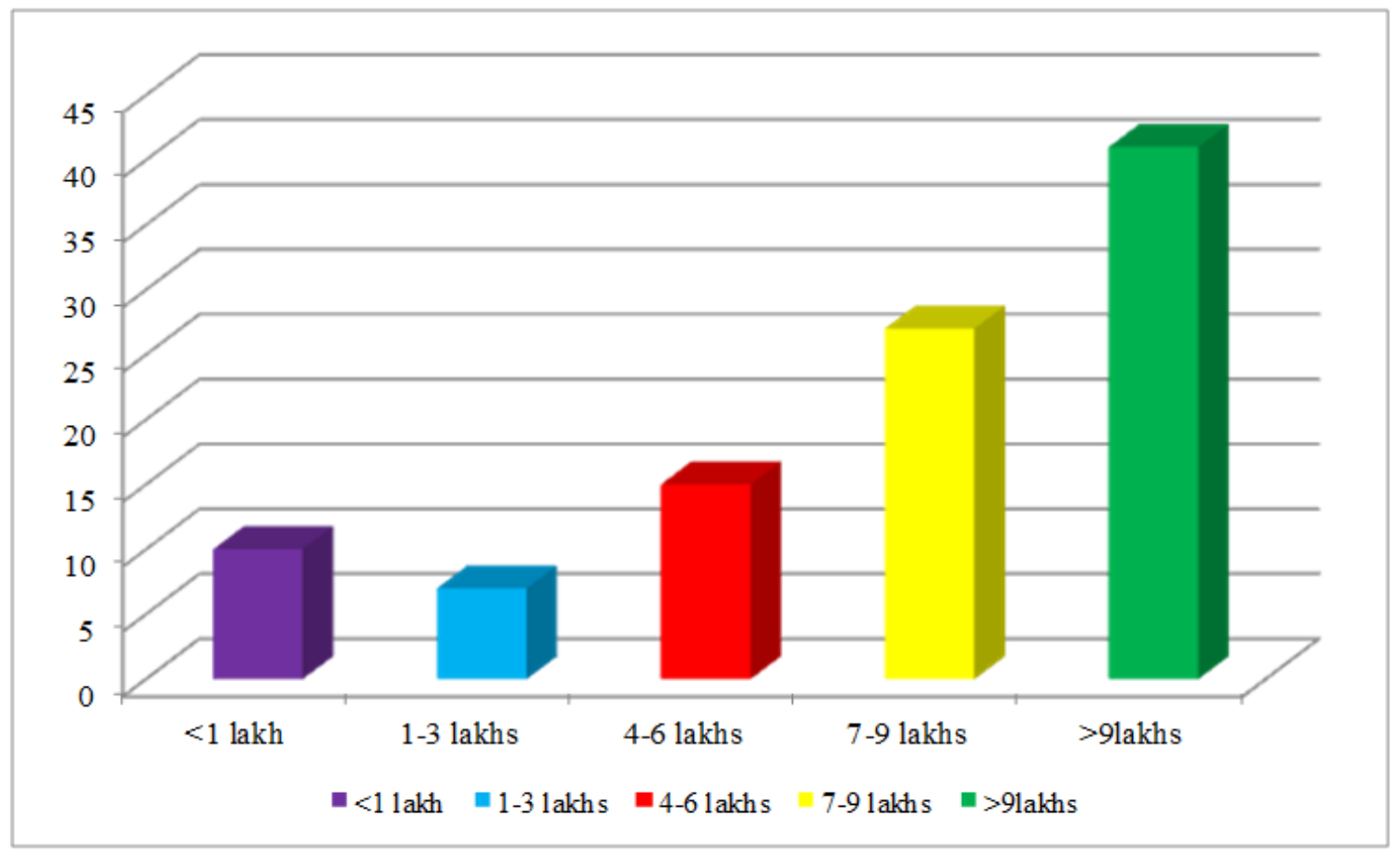

Fig.2 Medium influencing Sample Respondents awareness on Millet Products

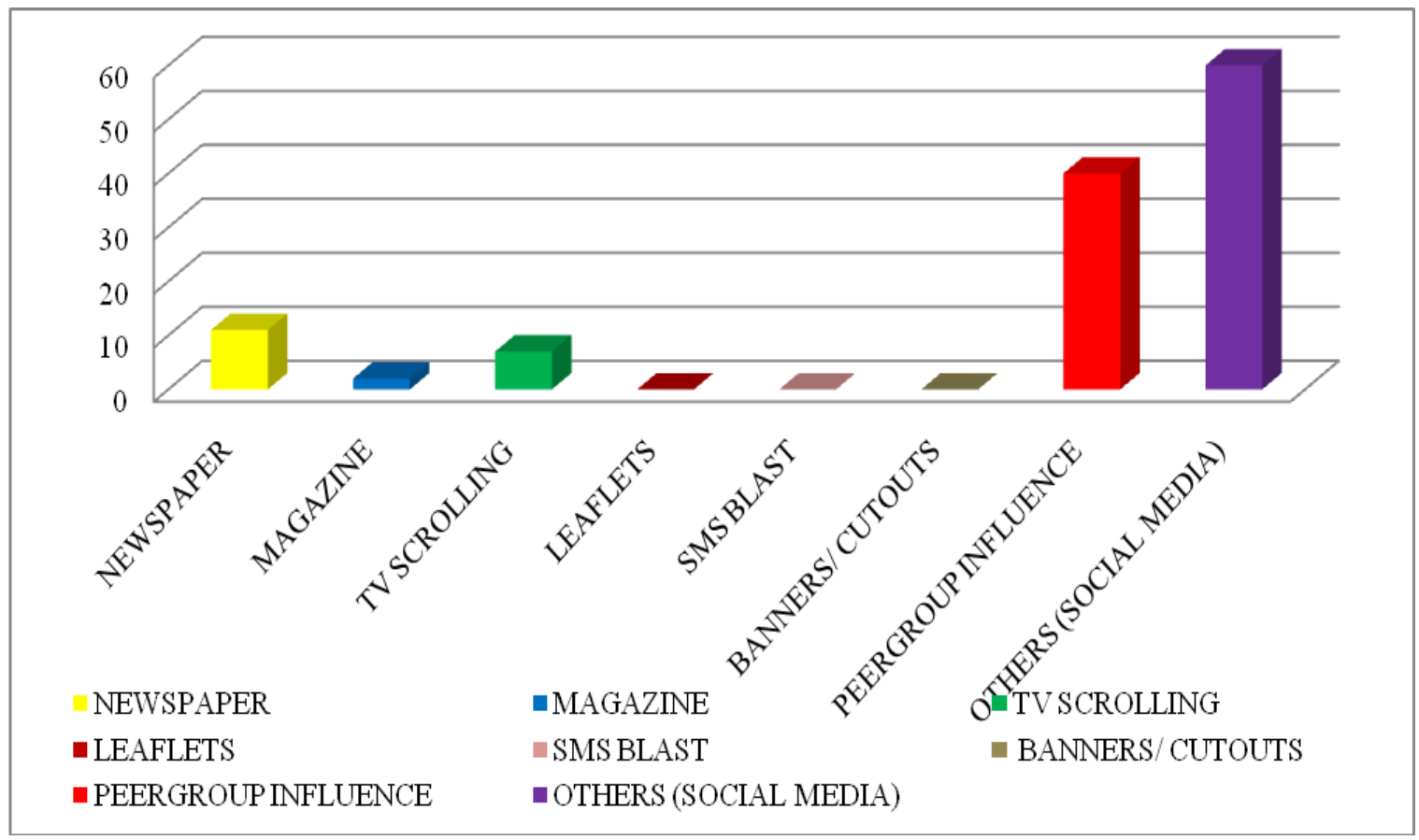




\section{ANNEXURE.1}

Attribute wise score for foxtail millet

\begin{tabular}{|c|c|c|c|c|c|c|}
\hline S.NO & Attributes & Very Poor & Poor & Average & Good & Excellent \\
\hline $\mathbf{1}$ & TASTE & 0 & 0 & 2 & 3 & 77 \\
\hline $\mathbf{2}$ & APPEARANCE & 0 & 0 & 3 & 31 & 48 \\
\hline $\mathbf{3}$ & TEXTURE & 0 & 2 & 9 & 40 & 31 \\
\hline $\mathbf{4}$ & FLAVOR & 0 & 9 & 12 & 4 & 20 \\
\hline
\end{tabular}

Attribute wise score for little millet

\begin{tabular}{|c|c|c|c|c|c|c|}
\hline S.NO & ATTRIBUTES & VERY POOR & POOR & AVERAGE & GOOD & EXCELLENT \\
\hline $\mathbf{1}$ & TASTE & 0 & 0 & 2 & 20 & 30 \\
\hline $\mathbf{2}$ & APPEARANCE & 0 & 0 & 5 & 28 & 19 \\
\hline $\mathbf{3}$ & TEXTURE & 0 & 0 & 14 & 25 & 13 \\
\hline $\mathbf{4}$ & FLAVOUR & 0 & 2 & 14 & 28 & 8 \\
\hline
\end{tabular}

Attribute wise score for pearl millet

\begin{tabular}{|c|c|c|c|c|c|c|}
\hline S.NO & ATTRIBUTES & VERY POOR & POOR & AVERAGE & GOOD & EXCELLENT \\
\hline $\mathbf{1 .}$ & TASTE & 0 & 0 & 0 & 7 & 5 \\
\hline $\mathbf{2 .}$ & APPEARANCE & 0 & 0 & 3 & 7 & 2 \\
\hline $\mathbf{3 .}$ & TEXTURE & 0 & 0 & 5 & 6 & 6 \\
\hline $\mathbf{4 .}$ & FLAVOUR & 0 & 0 & 3 & 8 & 1 \\
\hline
\end{tabular}

Attribute wise score for kodo millet

\begin{tabular}{|c|c|c|c|c|c|c|}
\hline S.No & Attributes & Very Poor & Poor & Average & Good & Excellent \\
\hline $\mathbf{1}$ & Taste & 0 & 0 & 4 & 23 & 15 \\
\hline $\mathbf{2}$ & Appearance & 0 & 0 & 13 & 21 & 8 \\
\hline $\mathbf{3}$ & Texture & 0 & 1 & 19 & 18 & 4 \\
\hline $\mathbf{4}$ & Flavour & 0 & 3 & 23 & 13 & 3 \\
\hline
\end{tabular}

Attribute wise score for finger millet

\begin{tabular}{|c|c|c|c|c|c|c|}
\hline S.No & Attributes & Very Poor & Poor & Average & Good & Excellent \\
\hline $\mathbf{1 .}$ & Taste & 0 & 0 & 6 & 16 & 21 \\
\hline $\mathbf{2 .}$ & Appearance & 0 & 1 & 10 & 24 & 8 \\
\hline $\mathbf{3 .}$ & Texture & 0 & 5 & 11 & 23 & 4 \\
\hline $\mathbf{4 .}$ & Flavour & 0 & 7 & 7 & 27 & 2 \\
\hline
\end{tabular}


Attribute wise score for proso millet

\begin{tabular}{|c|c|c|c|c|c|c|}
\hline S.No & Attributes & Very Poor & Poor & Average & Good & Excellent \\
\hline $\mathbf{1 .}$ & Taste & 0 & 0 & 2 & 13 & 7 \\
\hline $\mathbf{2 .}$ & Appearance & 0 & 0 & 9 & 10 & 3 \\
\hline $\mathbf{3 .}$ & Texture & 0 & 1 & 11 & 9 & 1 \\
\hline $\mathbf{4 .}$ & Flavour & 0 & 1 & 13 & 8 & 0 \\
\hline
\end{tabular}

Attribute wise score for jowar

\begin{tabular}{|c|c|c|c|c|c|c|}
\hline S.No & Attributes & Very Poor & Poor & Average & Good & Excellent \\
\hline 1. & Taste & 0 & 0 & 2 & 13 & 24 \\
\hline 2. & Appearance & 0 & 1 & 13 & 21 & 4 \\
\hline 3. & Texture & 0 & 1 & 13 & 21 & 4 \\
\hline $\mathbf{4 .}$ & Flavour & 0 & 1 & 11 & 21 & 6 \\
\hline
\end{tabular}

Attribute wise score for brown top millet

\begin{tabular}{|c|c|c|c|c|c|c|}
\hline S.No & Attributes & Very Poor & Poor & Average & Good & Excellent \\
\hline $\mathbf{1}$ & Taste & 0 & 0 & 0 & 3 & 33 \\
\hline $\mathbf{2}$ & Appearance & 0 & 0 & 1 & 17 & 18 \\
\hline $\mathbf{3}$ & Texture & 0 & 0 & 5 & 19 & 12 \\
\hline $\mathbf{4}$ & Flavour & 0 & 0 & 5 & 21 & 10 \\
\hline
\end{tabular}

ANNEXURE.2

Table Garrett Ranking: Standard Scores

\begin{tabular}{|c|c|c|c|}
\hline Rank & $\mathbf{1 0 0}\left(\mathbf{R}_{\mathbf{i j}} \mathbf{- 0 . 5}\right) / \mathbf{N}_{\mathbf{j}}$ & Per cent Values & Garret Values \\
\hline $\mathbf{1 .}$ & $100(1-0.5) / 5$ & 10 & 75 \\
\hline $\mathbf{2 .}$ & $100(2-0.5) / 5$ & 30 & 60 \\
\hline $\mathbf{3 .}$ & $100(3-0.5) / 5$ & 50 & 50 \\
\hline $\mathbf{4 .}$ & $100(4-0.5) / 5$ & 70 & 39 \\
\hline $\mathbf{5 .}$ & $100(5-0.5) / 5$ & 90 & 24 \\
\hline
\end{tabular}

ANNEXURE.3

Total Garrett Scores

\begin{tabular}{|c|c|c|c|c|c|c|c|c|}
\hline Attributes & $\begin{array}{c}\text { Foxtail } \\
\text { Millet }\end{array}$ & $\begin{array}{c}\text { Little } \\
\text { Millet }\end{array}$ & $\begin{array}{c}\text { Pearl } \\
\text { Millet }\end{array}$ & $\begin{array}{c}\text { Kodo } \\
\text { Millet }\end{array}$ & $\begin{array}{c}\text { Finger } \\
\text { Millet }\end{array}$ & $\begin{array}{c}\text { Proso } \\
\text { Millet }\end{array}$ & Jowar & $\begin{array}{c}\text { Brown top } \\
\text { Millet }\end{array}$ \\
\hline Taste & 2065 & 1600 & 393 & 1457 & 1428 & 775 & 1183 & 909 \\
\hline Appearance & 2511 & 1798 & 471 & 1661 & 1688 & 912 & 1625 & 1145 \\
\hline Texture & 2874 & 1987 & 628 & 1808 & 1843 & 985 & 1625 & 1279 \\
\hline Flavor & 3219 & 2104 & 486 & 1909 & 1871 & 1022 & 1573 & 1309 \\
\hline
\end{tabular}

After getting the garret score as shown above, the values of garrette divided by 100 
The brown top millet was rarely available in the market and there was demand from the respondents for brown top millet because of its multiple health benefits. There is a huge gap in the production and demand of the brown top millet.

Browntop millet is not only nutritious but also very delicious. The millet is gluten free and rich in essential nutrients. It is a rich source of natural fibre, when compared to other grains. Korale contains about $12.5 \%$ fibre due to which it serves as medicine for dealing with life style diseases. Lower incidence of cardiovascular diseases, duodenal ulcer and hyperglycemia (diabetes) are reported among those who regularly consume millets. Brown top millet is also grown and consumed in limited quantities in north central India (Reddy and Prasad, 2017).

\section{Attribute-wise Score for Consumer acceptance of Millet Products}

The consumer acceptance towards millet based products was influenced by various attributes. Therefore four major attributes such as taste, appearance, texture and flavour were identified and respondent's preference for different millets such as Sorghum, Pearl millet, Finger millet, Foxtail millet, Kodo millet, Proso millet, Barnyard millet, Little millet and Brown top millet was analysed by the responses of the sample consumers on a 5 point scale. A score 5 was given for excellent, 4 was given for good, 3 was given for fair, 2 was given for poor and 1 was given for very poor. Individual rating (5 to1) for, each millet is presented in annexure 1 . These ratings were analysed using garrette ranking method. Bases on standard garrette score (annexure 2), garrette ranking calculation was applied to the responses given my sample consumers and the total garrette scores obtained are presented in annexure 3. Based on the scores obtained, ranking was allotted and final results of garrette ranking method, is presented in Table 4.

From the results of garret ranking, it is shown that for foxtail millet flavor was ranked as first, texture was ranked as second, appearance was ranked as third and taste was ranked as fourth. For little millet flavor was ranked as first, texture was ranked as second, appearance was ranked as third and taste was ranked as fourth. For pearl millet, texture was ranked as first, flavor was ranked as second, appearance was ranked as third and taste was ranked fourth. For Kodo millet, flavor was ranked as first, texture was ranked as second, appearance was ranked as third and taste was ranked as fourth. For Finger millet, flavor was ranked as first, texture was ranked as second, appearance was ranked as third and taste was ranked as fourth. For proso millet, flavor was ranked as first, texture was ranked as second, appearance was ranked as third and taste was ranked as fourth. For jowar, texture was ranked as first, appearance was ranked as second, flavor was ranked as third and taste was ranked as fourth. In case of Brown top millet, flavor was ranked as first, texture was ranked as second, appearance was ranked as third and taste was ranked as fourth.

In foxtail millet for the consumer acceptance, flavor was the major constraint followed by texture, appearance and taste. For little millet for the consumer acceptance, flavor was the major constraint followed by texture, appearance and taste. For pearl millet, texture was the major constraint followed by flavor, appearance and taste. In the case of kodo millet for the consumer acceptance, flavor was the major constraint followed by texture, appearance and taste. For finger millet, flavor was the major constraint followed by texture, appearance and taste. For proso millet, flavor was the major constraint followed by texture, appearance and taste. For jowar, texture was the major constraint followed by flavor, 
appearance and taste. For brown top millet, flavor was the major constraint followed by texture, appearance and taste.

On a whole majority of the respondent's ranked flavour as a major attribute for consumer acceptance of the millet based product. Therefore the flavour part in millet based products should be enhanced to increase consumer acceptance by addition of natural or artificial essence.

The present era consumers have become health conscious and they prefer food substitutes to sustain their health and wellbeing. Therefore to further explore this concept a study was taken up on buying behaviour of consumers towards millet based food products in Hyderabad city of Telangana.

Primary data on factors influencing buying behaviour of millets and consumer acceptance of millet based products was collected from the respondents in the study area which was purposively selected for the current study.

Consumer perception about the millets is that they are good for health, easy for digestion, helps in weight reduction. Price of the millet based products weare high when compared with other food products.

Results revealed that income of the respondents was not influencing the purchase of millet based products because the income of majority of the respondents was more than five lakhs which shows that income and consumption of millet based products was not correlated but the quantity of the purchase was varying because of the price of the product.

Among all the channels of information dissemination on health benefits of millet products, social media has more influence as it can reach all the age groups easily.
The results prove that health benefits was the major factor influencing the consumption of millet based products by the respondents in the study area which is in support of the fact that millets are as one of the world's healthiest foods.

Majority of the millets were having high price and very few millets were having reasonable price which was affecting the purchasing decision of the consumer especially in the case of brown top millet.

All the millets were frequently available in the market except brown top millet which was rarely available and there was demand from the respondents for brown top millet because of its multiple health benefits.

Majority of the respondent's ranked flavour as a major attribute for consumer acceptance of the millet based product. Therefore the flavour part in millet based products should be enhanced to increase consumer acceptance by addition of natural or artificial essence.

\section{Policy Implications from the Present Study}

The following policy implications can be suggested from the present study

The government should include whole millet or millet based products as a part of diet in meals related schemes such as mid-day meals for government schools

Millet products should be made available as ration to the public through Public Distribution System along with rice, wheat, pulses, cooking oil and kerosene.

The government hospitals are already providing millets to patients suffering from mal-nutrition which should also to extended to all the patients keeping in view the nutritional benefits of millets. 
Earlier millets were considered inferior grains than cereals, therefore they very priced low. Due to increasing consumer awareness on health because of various health complications such as obesity, diabetes, calcium deficiency, constipation, gastric issues etc. the demand for millets and millet based products has risen up in cities and towns and places with higher educated population. Taking advantage of this scenario, the food processing companies have raised the prices of their branded millet products, mostly sold through organized retailing. Therefore steps should be taken to reduce the prices of millet and millet based products.

One major lacuna observed in millet based products was increased amount of impurities such as waste material and stones. Proper processing should be encouraged by the popular brand of millets.

\section{References}

Robert, R. (2004). The Encyclopedia of Nutrition and Good Health, 2nd Ed. Viva books Pvt, Ltd, New Delhi.

Bommy, D., and Maheswari, S. K. (2016). Promotion of Millets Cultivation through Consumption. International Journal of Current Research and Academic Review, Special Isuue 3:7480.

ICRISAT. (2016). Smart Food Millet Recipes. Patancheru, Telangana, India: International Crops Research Institute for the Semi-Arid Tropics. $32 \mathrm{pp}$.

NNMB. (2006). Diet and Nutritional Status of Rural Population and Prevalence of Hypertension among Adults in Rural Areas. NNMB Technical Report 24. National Institute of Nutrition, Indian Council of Medical Research, Hyderabad, India.

Gopalan, C., Rama Sastri, B.V and Balasubramanian, S.C. (2009).
Nutritive Value of Indian Foods, Hyderabad, India: National Institute of Nutrition, Indian Council of Medical Research.

Radhika, G., Sathya, R.M., Ganesan, A., Saroja, R., Vijayalakshmi, P. and Sudha, A. (2011). Dietary Profile of Urban Adult Population in South India in the Context of Chronic Disease Epidemiology (CURES-68). Journal of Public Health Nutrition. 14(4): 591598.

Ranjitha, D.T., Chimmad, B. V., and Prkasam, J. N. (2016). Ready-to-Cook Millet Flakes based on Minor Millets for Modern Consumer. Journal of Food Science and Technology, 53(2): 13121318. Retrieved from https://doi.org/10.1007/s13197-0152072-0

Sudha, A., Priyenka Devi, K.S., Sangeetha, V., and Sangeetha, A. (2016). Development of Fermented Millet Sprout Milk Beverage Based on Physicochemical Property Studies and Consumer Acceptability Data, Journal of Scientific and Industrial Research, 75(April), 239-243.

Samuel, J. (August 2016). Eat millets, Pay less, Stay Healthier, Save Earth, India Climate Dialouge, pp 1-12. Retrieved from

https://indiaclimatedialogue.net/2016/0 8/19/eat-millets-save-earth/

Rajput, L. P. S., Parihar, P., Dhumketi, K., Naberia, S., and Tsuji, K. (2019). Development and Acceptability of Novel Food Products from Millets for School Children, International Journal of Current Microbiology and Applied Sciences, 8(4): 2631-2638.

Ballolli, U., Chimmad, B.V. and Itagi, S. (2011). Storage Quality Evalution of Iron Enriched Garden Cress Seeds (Lipidium sativum L) Barnyard Millet (Echinochloa frumantacea) Cookies. 
NAIP: National Symposium Recapturing Nutritious Millets for Health and management of Diseases, UAS, Dharwad, December: 16-17.p41.

Varnashree, B.S., Rao, S.G. and Puttaraj, S. (2008). Quality Characteristics of Ragi (Eleucine coracana) based Idli. Indian Journal of Nutrition and Dietetics, 45:131-136.

Vijayakumar, P.T., Mohankumar, J.B. and Jaganmohan, R. (2009). Quality Evaluation of Chapatti from Millet Flour Blend Incorporated Composite Flour. Indian Journal of Nutrition and Dietetics, 46:144-154.

Kulkarani,L.R., Naik, R.K. and Rokade, C. (2011). Development of Nutri-cereals based Value Added Traditional Products and its Acceptability. NAIP: National Symposium recapturing Nutritious Millets for Health and management of Diseases, UAS, Dharwad. December: 16-17. Pp. 44.

Shukla, K. and Srivastav, S. (2011). Evaluation of Finger Millet Incorporated Noodles for Nutritive Value and Glycemic Index. Journal of Food Science and Technology, 40:5963.

Akoth, O.C., Ochanda, S.O., Afred, M.M., Kagwiria, O.J. and Mutiso, M.F. (2012). Development of Instant Breakfast Cereals from Optimized
Flours of Pearl Millet, Red and White Sorghum. Journal of Applied Biosciences, 51: 3559-3566.

Geeta, K., Mamta, K. and Prasad, P. (2012). Nutritional Scenario of Fast Food among Women in Bhagalpur Town, Bihar. 44th Nutrition Society of India National Conference Abstracts. 16-17 November. Thirupathi. p. 149.

Kalidas, K. and Mahendran, K. (2017). Research Paper on Buying Behaviour of Consumers towards Instant Millet based Food Products. Food Science Research Journal, 8(2): 196-202.

Sridevi, K.R. (Mar 2016). Here are a Million Reasons to Eat Millets. The Economic Times. Retrieved from https://economictimes.indiatimes.com/ magazines/panache/here-are-a-millionreasons-to-eat-millets/articleshow/ 51251177.cms?from $=\mathrm{mdr}$

Kulkarni, V. (Jan 2019). As Millets Turn Food of Choice in cities, Traders Reap a Rich Harvest. Retrieved from https://www.thehindubusinessline.com /markets/commodities/as-millets-turnfood-of-choice-in-cities-traders-reap-arich-harvest/article26053749.ece

Reddy, A. and Prasad, K.G. (Dec 2017). Return of the Forgotten Crop - Brown Top Millet, Millet Farming Systems, Leisa India, 19(4). Retrieved from https://leisaindia.org/return-of-theforgotten-crop-brown-top-millet/

\section{How to cite this article:}

Alekhya, P. and Raj Shravanthi, A. 2019. Buying Behaviour of Consumers towards Millet Based Food Products in Hyderabad District of Telangana, India. Int.J.Curr.Microbiol.App.Sci. 8(10): 223-236. doi: https://doi.org/10.20546/ijcmas.2019.810.023 